\title{
2.6. USING COACHING-ORIENTED MANAGEMENT STYLE
}

\begin{abstract}
Summary
Most of people want to change certain aspects of their personal lives or professional careers. However, these needs are not always easy to be met since they are often challenged by fear of changes and reluctance to change. Coaching is a method which, with the help of an expert, allows for realization of problems and working through all that prevents a person from changes, and, based on our own resources, plan and take actions that allow for achievement of the set goal. Coaching can be also used in the work of a manager. Managers using coaching style for management develop some beliefs and behaviours that help them evaluate and stimulate others to think independently, act and encourage them to take responsibility for the effects of work. Therefore, a manager can be relieved from the pressure of constant supervision, leading and worrying about results and can focus on creation of conditions which ensure that his or her employees are able to present knowledge, experience and ability to create their own solutions.
\end{abstract}

Keywords: change, coaching, resources, manager, leadership styles, coaching style for management

\section{Introduction}

The need for changes is rarely accompanied by making actual changes in life. Our thinking about changes is often associated with apprehension of the unknown and the related reluctance to abandon what is known and entering the new unpredictable reality. This causes that people prefer to choose the known reality they have accustomed to living in, despite the inconveniences they might sometimes experience. Covey (2014) wrote that „Each of us guard a gate of change that can only be opened from the inside". One of the methods to help "open the internal gate" and to cause the demanded changes in personal and/or professional life is the use of coaching. Similar to the world, a dynamic development of coaching has been observed in Poland, with its professionalization and specialization (e.g. executive coaching, managerial coaching, career coaching, team coaching, sports coaching, life coaching). As noted by Williams (2013), ,coaching is the second fastest growing profession in the world".

The paper characterizes the concept of coaching and its basic principles. It also discusses manager's abilities that help them use coaching style in management to increase the potential of their teams. 


\section{The concept and basic principles of coaching}

Coaching is a discipline that is constantly developed. A great number of its definitions have been coined, followed by constant attempts to create the adequate conceptual apparatus and to define its own boundaries and care for distinction from other disciplinesi.e. consulting, psychotherapy, mentoring, counselling(Marciniak 2009).

The concept of coaching stems from the world of sport, where outstanding coaches do not necessarily have to be outstanding athletes in order to coach others successfully. However, they are characterized by an ability to bring out the maximum abilities from the athletes in order for them to show top performance. The concept of coach can also be referred to the field of transport since the buses that transport passengers are also termed coaches. With this approach, coaching services can be understood as services where customers are "transported" by means of their "coach" from one place (where they are now) to the other (where they chose to get to) (Bobrowska-Drozda, 2009).

Wujec (2013) analysed the literature concerning coaching which has been present in the world since the last 40 years and identified the components to be dominant in an intervention in order for it to be termed coaching. These include: attitude towards developing the potential of the person and environment they develop in, striving for achievement of the goals, finding the solutions, improvement in efficiency; support for development of customers that is consistent with the values they believe in; partnership relations between a coach and customers; emphasizing that this is a process of support; being based on the conversation with feedback to customers, caring for the customers to find solutions by themselves; supporting customers in overcoming internal limitations, emphasis on short-term interventions.

Coaching is based on the following principles:

- each customer has the resources to be used when solving their own problems,

- with coaching, customers have opportunities for using the resources they have and they might not realize and customers can build new resources;

- customer is the wholeness, also with respect to time (their past, present and future are equally important),

- topic of the session is always chosen by the customer,

- customer and coach are partners, their cooperation is based on mutual respect,

- coach helps customers to take actions that allow for making a change, which is the goal of coaching (Rogers, 2013).

The above principles can be supplemented by coaching principles used in Erickson's approach, which were formulated in the following manner:

- people are okay as they are. nobody is wrong and nobody is "broken", nobody needs repairing,

- people always make the best choice they can at the time,

- every behaviour has a positive intention,

- change is inevitable (in: Wilczyńska et al., 2013).

According to Wilson (2010), coaching helps customers develop their self-awareness, their choices and decisions; deepen the self-confidence since they are encouraged to exercise, make mistakes, experience; focus on finding solutions rather than on problems; search and discover new prospects that encourage them to act and change. 
In conclusion, coaching can be viewed as partnership relation based on mutual trust between a properly prepared coach and a customer where, through conversation, asking questions by the coach, receiving the feedback and helping remove internal barriers, customers are motivated for determination of the goal they aim to achieve and to achieve the goal based on their own values and resources.

\section{Effective leaders}

Goleman (2006a) describes the results of a survey carried out among a random sample of nearly 4,000 managers all over the world and found six leadership styles that engage various areas of emotional intelligence:

\section{The Commanding Leader}

- the leader demands full compliance from employees,

- is oriented at achievement and demonstrates high self-control,

- communicates with their employees by saying: „Do what I tell you!”

- all the decisions are made using a top-down approach,

- employees feel no respect for the job, no satisfaction from the work performed, inability to present the initiative and do not feel responsible for the outcomes of their work and cease to identify with the work,

- this leadership style has a negative effect on the climate at work,

- it is effective in the situation of crises, threats and disasters,

- it should be used very carefully, only if necessary.

2.The Visionary Leader

- the leader is a visionary, self-assured, with high empathy, able to make changes,

- communicates with their employees by saying: „Follow me!”

- motivates employees to realise a far-reaching vision by explaining why the work they do is important for the enterprise,

- indicates the goal, sets standards but lets the employees choose the resources used to achieve the goals,

- encourages to experiment and take a balanced risk,

- is able to motivate employees to be maximally involved in achievement of the goal,

- this leadership style has a positive impact on climate at work.

3.The Affiliative Leader

- the leader concentrates on building harmonious interpersonal relations,

- communicates with their employees by saying: „People first!”,

- employees are loyal, have high level of trust and sense of affiliation with the enterprise,

- communication and mutual inspiration is essential,

- leaders provide a lot of positive feedback concerning employees' performance,

- this leadership style has a positive impact on climate at work.

\section{The Democratic Leader}

- this leader expects the support from the employees,

- and asks the employees: „,What do you think about it?”, 
- stimulates the climate of commitment, respect and trust,

- the flexibility and sense of responsibility of employees is improved through ensuring the effect on the choice of the aim and methodology of working,

- an irritating consequence of this style is never-ending meetings,

- this style works best when the leader seeks ideas for objectives that have to be adopted in the enterprise and needs the support of competent employees.

\section{The Pace-Setting Leader}

- the leader sets very high standards, expects high commitment from employees,

- communicates with their employees by saying: „Do what I do, without thinking",

- demands excellence,

- puts pressure,

- replaces poor performers with better employees,

- this style produces high effects since employees are self-motivated, work independently and demonstrate high competencies,

- this leadership style has a negative effect on the climate at work; therefore, it should be used rarely.

\section{The Coaching Leader}

- the leader helps employees discover individual strengths and weaknesses and link them to life and professional aspirations,

- is emphatic, self-aware, oriented at supporting development and education of employees,

- communicates with their employees by saying: „Try it this way!”,

- encourages people to set development goals and helps develop the plan to achieve the goals,

- delegates authority, assigns responsible tasks to employees, accepts temporary failures focusing on a long-term process of education,

- remains in dialogue with the employee and offers constructive feedback,

- this leadership style has a positive impact on commitment and climate at work,

- $\quad$ it is the least frequent leadership style.

The conclusions drawn from the survey are very interesting. The survey demonstrated that the most effective leaders use various leadership styles by adapting to what happens in the enterprise. The effective leader is similar to a professional golfer who chooses between the golf clubs he has (= leadership styles) to find the one that is best for the shot he wants to perform. According to Goleman, the best results and the best atmosphere at work is achieved by leaders who are able to use at least four leadership styles, especially visionary, democratic, affiliative and coaching leadership styles. The author encourages leaders to extend their "repertoire" of styles used in management. Furthermore, a solution for the leaders without abilities to use various leadership styles can be to develop a team with individual team members using the styles not demonstrated by the leader.

The effective leaders are also distinguished by a high level of emotional intelligence (Goleman, 2006b, 1999). They understand their own emotions, know what effect they have on other people, know their own strengths and weaknesses, are self-assured, have a realistic self-assessment, and know where they are going to and what is important in 
their lives (self-awareness). They are able to control their own emotions and impulses and are open to changes (self-control). They want to improve themselves and the enterprise, love working and are persistent, ambitious and committed to work for the enterprise and optimistic in difficult times (motivation). They respect others' feelings and cultural differences, are kind to people, ready to promote and develop talents of their employees (empathy). They easily start contacts with others and share the same attitudes with them, are able to persuade others, create and manage employee teams (social skills).

\section{Coaching as a management style}

Managers' work can be also based on the assumptions of coaching through implementation of coaching-oriented management style. This management style can be approached as a combination of the two above mentioned leadership styles (coaching and affiliative), with managers especially interested in such problems as:

- development of their own emotional intelligence and employee's intelligence,

- remaining in the dialogue with the employee,

- providing them with constructive feedback,

- stimulation of the climate of trust in the enterprise,

- helping employees find their strengths and weaknesses,

- helping employees to set and realize their life goals and professional goals,

- improving the level of responsibility for their own development and development of the enterprise etc.,

In her book Brilliant Coaching. How To Be A Brilliant Coach In Your Workplace, J. Starr (2011) described what this management style is and compared it with the directive style. Although the directive management style might be sometimes efficient and necessary, it might soon become a real trap for the manager. It is connected with the pressure, incessant feeling of responsibility for the team; searching for solutions, making decision, control over the team and caring for the outcomes. The manager who acts according to: „I know the best what to do", „I'm telling you”, „Do what I told you” will sooner or later cause that:

- the employees will lack creativity, drive for work and commitment,

- the employees will feel boredom,

- the manager will expect more from themselves, which substantially limits his or her time for performing other tasks,

- will make employees dependent on him or her.

The manager who uses coaching as a management style creates the conditions where it is possible for the employees to act independently and be successful. This manager encourages employees to make decisions and solve problems they face, which translates into the enhanced involvement, self-confidence, feeling of empowerment and taking responsibility for the effects of activities.

Starr (ibidem) argued that the most important skills of a manager who wants to use and develop coaching-oriented management style are:

- building a good contact with another person (creation of relations, feeling of ties, climate of trust, ability to find similarities between interlocutors), 
- taking conscious effort to listen carefully and perceptively (concentration, focus of attention, being present here and now, helping interlocutors to express themselves, awareness of various obstacles to communication),

- asking questions to help other people rethink and understand the situation, encouraging them to think independently, make decisions and act (simple questions with clearly formulated goals with open character, using "strong questions"),

- constructive feedback (positive intention, caring that the other person should actually benefit on what he or she hears; commenting on the behaviour rather than on the whole person; care for being objective; balance between positives and negatives; ensuring that the interlocutor understands the message and is involved in the conversation; helping when making decisions).

According to Szmidt (2009), coaching, oriented at development of employees, can be used in the enterprise as one of the most important tools to support human resource management. This author used a model proposed by P. Hawkins to identify the stages in the process of building coaching culture in an organization. These include:

1. analysis and determination of the goal of implementation of coaching culture (detailed determination of the role of coaching in management of human resources and business strategy, preventing from coaching culture being considered as a temporary fashion to be interested in in order to be successful),

2. creation of relationships between the strategy for building coaching culture and general strategy and the strategy for human resource management (realization of changes stimulated in the enterprise by implementation of the coaching culture e.g. changes in the philosophy and structure of the enterprise, development of competencies of employees and increasing their independence and responsibility; improved flexibility),

3. objective analysis of current and future company culture (utilization of all positive components of previous business culture for building the coaching culture; inclusion of all employees in the process of building the coaching culture),

4. initiation of the process of project consultations and cooperation with previous leaders (making leaders realize differences between current and desired business culture; involvement of leaders in the process of changes),

5. selection and development of the group of external coaches (finding external coaches with adequate qualifications to help implement changes; creation of the coaching community with shared goals),

6. using coaching among both selected individuals and teams or organizational units (using coaching for all employees; individual and team coaching),

7. building of internal coaching potential (training internal coaches who are familiar with internal enterprise's culture and combining their activities with the activities of the external coaches),

8. implementation of training for the whole managerial staffs concerning fundamentals of coaching (involving managers in the coaching culture through teaching them coaching skills and making perceive the benefits of such activities and encourage to utilize new skills at work), 
9. linking coaching processes with all other activities in the area of human resource management with evaluation of the effectiveness (using coaching in various areas of human resource management, such as recruitment, motivation of employees and training; evaluation of economic effectiveness of the actions taken),

10. analysis of opportunities for the use of coaching to build relationships with other groups of stakeholders (training and/or coaching for shareholders and customers in order to build strategic partnership),

11. regular evaluation of the coaching process and its participants (periodical evaluation of the outcomes of coaching process and introduction of demanded corrections).

\section{Conclusion}

Coaching is becoming a tool which can be successfully utilized for both development of individuals and organizations. Individuals are supported in planning and carrying the demanded changes. Organizations can utilize coaching for implementation of the company strategy. A manager that uses the coaching-oriented management style in an organization that builds the coaching culture stimulates development of competencies and independence in employees, which can be translated into the enhanced competitiveness of the enterprise in the market. Furthermore, the manager who learns the coaching-oriented management style, extends the repertoire of the leadership styles, which does not only improve its efficiency in workplace but also positively affects the atmosphere among all employees.

\section{References}

1. Bennewicz M. (2011): Coaching i mentoring w praktyce, Wydawnictwo $\mathrm{G}+\mathrm{J}$.

2. Bennewicz M. (2014): Coaching, kreatywność, zabawa. Narzędzia rozwoju dla pasjonatów i profesjonalistów, Wydawnictwo HELION.

3. Bobrowska- Drozda Ł. (2009): Zawieranie kontraktu coachingowego, [in:] SidorRządkowska M. (ed.): Coaching, teoria, praktyka, studia przypadków, Oficyna Wydawnicza Wolters Kluwer Polska.

4. Covey S. R. (2014): Mądrość i pasja, Dom Wydawniczy Rebis.

5. Goleman D. (2006a): Przywództwo, które przynosi efekty, [in:] Atrybuty przywódcy. Harvard Business Review, Wydawnictwo Helion, Gliwice

6. Goleman D. (2006b): Co czyni cię przywódcą?, [in:] Atrybuty przywódcy. Harvard Business Review, Wydawnictwo Helion, Gliwice

7. Goleman D. (1999): Inteligencja emocjonalna w praktyce. W jaki sposób inteligencja emocjonalna pomaga odnieść sukces zawodowy, Media Rodzina, Poznań

8. Kimsey-House H., Kimsey-House K., Sandahl P., Whitworth L. (2014): Coaching koaktywny. Zmiany w biznesie, zmiany w życiu, Wolters Kluwer Polska.

9. Marciniak Ł. T. (2009): Przegląd istniejących definicji coachingu, [in:] Sidor-Rządkowska M. (ed.): Coaching, teoria, praktyka, studia przypadków, Oficyna Wydawnicza Wolters Kluwer Polska.

10. Rogers J. (2013): Coaching, Gdańskie Wydawnictwo Psychologiczne. 
11. Rzepa T. (2006): Psychologia komunikowania się dla menedżerów, Difin.

12. Starr J. (2011): Coaching dla menedżerów. Słuchaj, motywuj i zwiększ potencjał zespołu, Samo Sedno.

13. Szmidt C. (2009): Coaching a zarządzanie strategiczne, [in:] Sidor-Rządkowska M. (ed.): Coaching, teoria, praktyka, studia przypadków, Oficyna Wydawnicza Wolters Kluwer Polska.

14. Wilczyńska M., Nowak M., Kućka J., Sawicka J, Sztajerwald K (2013): Moc coachingu. Poznaj narzędzia rozwijające umiejętności i kompetencje osobiste, Wydawnictwo HELION.

15. Wilson C. (2010): Coaching biznesowy. Praktyczny podręcznik dla coachów, menedżerów i specjalistów HR, MT Biznes.

16. Williams R. (2013): The second-fastest growing profession, [in:] Czarkowska L. D., Wstęp, „Coaching Review”1 (4), p. 2.

17. Wujec B. (2013): Geneza i definicje coachingu, „Coaching Review”1 (4), p. 4-28. 